\title{
Marietta the White Goat and the Motel
}

\author{
Jay Cates
}

It inight be nice to be in love.

It might be fine to die.

When I left my last home I added, but it's sure good to be gone.

I drove straight south, or almost straight south; I was leaving for good again. A fever of the first day of driving kept me going after I had started to fall asleep, that and a big bag of weed under the dashboard that there was no reason to close, driving with just one hand on the right side of the wheel so that when I fell asleep my hand would pull the wheel to the right, and going onto the gravel shoulder would wake me up so I could steer back to the road. After Clel Elum I fell asleep with my eyes open, watching the taillights on the truck ahead of me move apart as my eyes lost their focus, and it was late.

Before I came to the next town I drove onto a side road and parked by some willows. I let Marietta the white goat out of the back seat and tied her to the bumper so she could sleep outside. Before we left I'd taken out the back seat so she'd have more room and so she could reach the bale of hay in the trunk. There was an old blanket on the floor so I could shake the shit out every day. She'd finally gotten to like driving but she still liked to sleep outside. I preferred the front seat, with the windows open. Man can go anywhere ifn he's got his goat with him.

I woke up a couple hours later, dawn, to a loud MA-A-A-A coming through the window. As usual. Waited for Marietta to relieve herself, milked her, put her in the back seat and started driving again. Idaho and Utah were boring; by then I was used to people passing and staring, laughing or snarling, or all three, one after the other, Shitkickin' farmers. Once in a while a real smile. Big deal.

-What happened to people and towns, old goat? It's all stupid grinning tourists in campers and sniveling grinning gas pumps for them. It's all motels, Marietta old goat, all motels motels motels.

$-\mathbf{M A}-\mathbf{A}-\mathbf{A}-\mathbf{A}$ 
And with that happy bleat we rolled into Salt Lake City just at rush hour. The looks we got from drivers were no longer of interest. A goat always has a dumblooking goat look on its face. Always, so do most people who look at goats. I did notice though that the looks were more confused then than laughing. See, the goat was in the habit of sticking her head over the front passenger seat to look out the front window. I heard a muffled ma-a beside me and assumed without looking she was just talking with her mouth full, as she often does. When I heard another muffled bleat and felt her banging my shoulder I looked-I carry crackers and cheese and bread when I drive-she had shoved her head into the large two-pound cracker box and her horns had stuck inside the lid: she looked like a white goat with her head stuck in a cracker box to me and godknowswhat to cars passing with just a second to look. I had to stop for gas just as we were leaving town, and gave the white goat some water and a handful of oats to make up for laughing at her. She ate daintily, forgiving with her dumb goat look restored.

The chubby attendant, whose name, Randy, was forever stitched on his blue shirt, had it filled up before he managed to ask

-What's that you got in there?

-My dog.

-That don't look like no dog to me. Looks like a goat!

-Can prove it. Look,

I said, showing him the cute little dog license in the shape of a fire hydrant that I'd got Marietta before we left.

-Well-it's the funniest lookin' dog I-what about the

he said, starting to think it was a put-on and wanting to laugh, but I had him scared by then.

-Cross between a collie and an Afghan. Albino.

I said, looking him right in the eye.

-Lassie-bark for the man

as I got into the car

-MA-A-A-A

-She has a cold,

I called as I drove out into traffic and kept driving right out of town and onto the highway south again, still laughing, never paid for the gas.

II

We finally were out of the dirty brown sagebrush desert and into Colorado. As the station wagons passed us the husbandwife in the front always sneered, as the kids in the back smiled and flashed peace signs. I flashed three fingers back to confuse the little fuckers. That night I put Marietta out, leaving the trunk open because there was nothing for her to eat outside. I slept on my back on the seat, looking up through the windshield at the stars, thousands of stars that I felt were 
there just for me that night, to cry with me into the lonely Colorado desert. And I celebrated with the dawn.

-Look, old goat, look at that huge butte or whateverthehell over there, like someone just piled up huge slabs of rock one at a time, just so the sun could come up and hit it, now, Now, and look where the shadow goes, and how big it is, all the way to the hills-look at the colors way over there, old goat, the red from the sun is hitting the orange in that, thing, now they're both turning yellow. Look how empty it all is, Marietta. We couldn't see all this last night but yes we're going to see it all today; come, we shall leave before it gets too hot,

and we started driving again. I drove with my head out the window, partly for the wind in the heat, partly for the excitement of watching the dotted white line flash under me, coming up to every pebble in the road forever and leaving every pebble in the road behind forever. I could stare at the colors of the rocks in asphalt; that day I stared at a rainbow as I moved through it. Occasionally I looked down the road; occasionally I looked into the car from outside, at the goat, the steering wheel, my hands on the wheel and my body, all moving along in the car. We stopped for gas in Cortez.

-What's at?

the attendant said, pointing, after he'd filled the tank and come to my window. I handed him a bill and turned my head away, looking out the windshield, silent. When he brought the change I took it and leaned my head out the window and said, with the voice and the face of an undertaker

-Man can go anywhere ifn he's got his goat with him.

And started driving slowly away, my head still out the window looking at him, until I had to turn to find the road.

When I was young I wanted to travel around. I thought the whole world, people, and everything in the world important to me was an illusion created by superior beings, all for me, because I was crazy and they were too humane to kill me. So I wanted to move around and make the illusion harder to maintain, to prove I was right. I proved I was wrong but I still have to move. No one ever really changes.

We got near El Paso late at night, getting lost on a grid of roads with single white lights at the intersections only, which were far apart-but the land was so flat I could see the lights far away at other corners. Ours was the only car and it was like traveling on the eye of a giant spider, through points of light reflected on his eye. And then a store open, and we found the road into El Paso. But first I let the goat out for a walk, milked her, shook the shit out of the car, then we drove into town, going down a long hill with the town in the distance spread out in front of us. I stopped at a motel before we were down the hill. I've always thought it was crazy to have to spend five or ten bucks for a place to sleep for a few hours when there were so many people with extra room and so much room 
outside, if police didn't always make you go inside. So when I stayed at a motel I took three showers and watched TV and stayed until checkout time. I was hoping for four dollars. I picked that motel because it looked cheap and because it was a bunch of little cabins and not too close to the city, so I hoped they wouldn't mind the goat. Went into the office, there was no one there, but the door was open and the light was on so I sat down to wait.

I sat about an hour, telling myself every few minutes that this was stupid, that someone must come soon. A tall skinny guy with a crewcut came in, looking suspiciously, looking at me sideways, haggard from driving.

- Hi. Can we get a room?

-Wouldn't know. I'm just waiting for the manager to come back myself.

-What's at?

-Waitin for the manager myself.

-Oh. Place down the street I'll go to then. You gonna wait?

-Yeah. Hate to waste the time I already waited.

He left. I sat in the bright room and watched the dark street; the window looked dark with the street behind it, even the glass. A radio played bad country music, pushed it through the hot air from a long way away. The air was hot if you moved too fast in it, but a breeze that started and stopped made the night cool after the desert; the cars coming down the hill seemed like big caterpillars, looking for something.

A fat tourist stumbled in.

-Got a room?

-Manager's not here.

-Uh.

He left. Ridiculous situation to be in. (I'd already looked and there was no money around.) But some drunk might come in and smash everything. I wouldn't mind taking some bread, but the guy shouldn't have to come back and find his place all busted up, that's a drag. Might be a sweet young chick looking after it too, and maybe she'd get in a lot of trouble if someone wrecked the place while she maybe just ducked out for awhile. Might be out getting some wine. I'll stay a little longer. Like to turn on the no vacancy sign and close up-but it might be a trap, maybe they're watching-better just sit awhile. A young nervous couple come in. Hah! Bout time we saw some action here. Oh shit, they must really be scared if they came this far from the city.

-Can we have a cabin? for the night?

she added actually blushing through a smile. Hiding their hands, oh shit, hope they didn't see me look.

-Well the manager's not here-oh, here's the keys. Look, I guess this one's empty cause the key's here. Why don't you just take it and you can pay the manager in the morning. If you see him.

-Thanks sport,

he said, taking the key and slipping me a five so smoothly I hardly noticed. Shit, he's been around. Probably just everyone in Texas looks nervous. I tied the 
goat behind the nearest cabin and slept in it for the hour before dawn. To hell with the damn office. And the wine.

But in the morning I was still tired, so I decided to stay another day. Curious too. I closed up the cabin because I knew if the guy came back he'd try to charge me anyway, even if I did look after his goddamn place for him. So I sat in the office and waited some more. The nervous couple left without coming to pay. I went over to their cabin and got the key and straightened up a little. Well someone had to. Besides, it might have been part of the trap. To hell with them too.

A few minutes later a fat businessman came in.

-Can I have a room please? Like to clean up a little before I try to sell anything.

OK a salesman then.

-Sure. Take any one. What the hell.

-Uh-could I have the key then please? And how much is it please?

-Oh. Yeah. Sorry. Here you go. Five bucks?

-Great. Thank you.

And then an official looking dude edged into the office, looking around, but mostly at me, quiet but aggressive-like.

-I'm from the city. Like to ask you something if I may.

-Sure.

(The Goat!)

-Uh-that old school bus parked over there, the one with the curtains? Wonder if you might know anything about it.

(Not The Goat!)

- No, not really. Sir.

-Well, we had a report that there were some, uh, hippies living in it. Have you seen any of these people?

- No, not really. I've seen the bus, but no people.

-Well. Too bad. Thought maybe you'd have seen them, working here and all -heard a bunch of them were living in it, and they can't do that.

- No, haven't seen. Sometimes a bunch'll live in a place like that though. I've heard.

-Yeah, I know. Could be ten or fifteen in there, that's what we'd like to find out.

-Yeah, my cousin-in Frisco-said she's seen maybe twenty in a place no bigger than that. Like rabbits.

-Yes. Well, uh, just thought maybe you'd have had some contact with them, because of your, uh, appearance.

-Uh, no. But I haven't been here long.

-Yes, we know. 
By the afternoon I had sold two more rooms, taking care to leave a careful note in the desk saying I had taken in so much money and would be in cabin one. I had another note ready that said the same, but included the five bucks I had had slipped to me; I just couldn't decide about that. And I've carefully written two more notes every time I got some money for the last week, and destroyed the previous notes. I charged a couple people ten bucks for giving me dirty looks. It might be nice to be in love. 